\title{
Corporate Social Responsibility and Pro-Environmental Behavior of the Individuals from the Perspective of Protection Motivation Theory
}

\author{
Ghulam Jilani ${ }^{1}$, Guangqin Yang ${ }^{1,2, *}$ and Irfan Siddique ${ }^{3}$ \\ 1 School of Education, Zhengzhou University, Zhengzhou 450052, China; jilani_101@gs.zzu.edu.cn \\ 2 Voice President and Secretary General of Henan Education Quality Society, Zhengzhou 450001, China \\ 3 Faculty of Management Studies, University of Central Punjab, Lahore 54000, Pakistan; irfans@ucp.edu.pk \\ * Correspondence: guangqinyang@sina.com
}

\section{check for}

updates

Citation: Jilani, G.; Yang, G.; Siddique, I. Corporate Social

Responsibility and

Pro-Environmental Behavior of the

Individuals from the Perspective of

Protection Motivation Theory.

Sustainability 2021, 13, 13406.

https://doi.org/10.3390/

su132313406

Academic Editors: Wen-Hsien Tsai and Cheng-Tsu Huang

Received: 26 October 2021

Accepted: 24 November 2021

Published: 3 December 2021

Publisher's Note: MDPI stays neutral with regard to jurisdictional claims in published maps and institutional affiliations.

Copyright: (c) 2021 by the authors. Licensee MDPI, Basel, Switzerland. This article is an open access article distributed under the terms and conditions of the Creative Commons Attribution (CC BY) license (https:/ / creativecommons.org/licenses/by/ $4.0 /)$.

\begin{abstract}
Several research studies have investigated the relationship between corporate social responsibility (CSR) and pro-environmental behavior of individuals in the industrial context (considering the employees as individuals) while ignoring the non-industrial context. Climate change and related issues associated with the interaction of humans with the environment are of great importance in today's context, hence, it is equally important to test such a relationship in a non-industrial context. Therefore, the current study aims to investigate the relationship between CSR and pro-environmental behavior of students (SPEB) in the higher education sector of Pakistan. Given that university students are more inclined to act pro-environmentally, as they partake in different climate change activities and are part of the debate on the global environmental crisis, considering this sector to promote SPEB is of the utmost importance. The current study also proposes emotional affinity towards students (EATN) as a mediator between the proposed relationship. The current study data were collected from university students $(n=656)$ studying in different universities of Pakistan. The results were validated by employing the structural equation modeling technique (SEM). The results confirmed that there exists a positive association between CSR perception of a university and SPEB, and EATN partially mediates this relationship. The findings of the current study will be helpful to the higher education policymakers in Pakistan to mitigate the country's environmental footprint by promoting the sustainable behavior of students as an outcome of CSR. Moreover, these findings will also be helpful to the academia for policymaking pertinent to educational governance.
\end{abstract}

Keywords: corporate social responsibility; pro-environmental behavior; sustainability; higher education; emotional affinity; stakeholders; educational governance

\section{Introduction}

Although the revolutionary industrial progress has improved productivity, the overuse of natural resources and an increase in consumption rate on the part of individuals has been creating a negative impact on the environment [1]. Global warming, water scarcity, air pollution, ozone depletion, deforestation, and damaged wildlife are significant environmental problems that exist now, endangering the planet and the people with calamities and disasters [2]. Many environmental challenges prevail due to inappropriate human behavior towards the environment, therefore, contemporary scholars believe these problems can significantly be reduced by promoting the individuals' pro-environment behavior (PEB) $[3,4]$. This concept emerged during the 1960s and 1970s, increasing interest in environmental studies in education and sciences [2]. Thus, scholars in psychology, the environment, agriculture, social work, anthropology, and political science all began to bring scientific knowledge to the studies related to environmental management and how such issues can be addressed by shaping human behavior [5]. Notably, the research on environmental behavior during the 1960s was mainly concerned with measuring public concern for the 
environment's well-being [6]. Over time, by increasing public interest in the study of the natural environment, questions about the critical factors that lead to the acceptance of a permanent eco-friendly behavior have occupied the minds of researchers [7]. Following this development, much research was carried out to understand the environment-specific behaviors between different social groups such as employees [8,9], consumers [10], farmers [11], and others. From the perspective of sustainable development goals (SDGs), and responsible consumption and production (goal-12), it was established that the climate crisis can be addressed by raising individual awareness to realize the importance of ecofriendly behavior at every level [12]. To expand further, a recent report by the United Nations Environmental Program (UNEP) has mentioned that responsible behavior at the level of the individual can significantly mitigate the recent climate crisis [13]. To hope for a better and sustainable future, responsible individual behavior is critical to preserve the environment. This is why different scholars have acknowledged the importance of PEB to achieve SDGs developed by the United Nations [14,15]. From a business context, it is already established that an organization's engagement in different sustainability initiatives can have a significant impact on SDGs. However, in a non-business context (i.e., the current study's context), the literature is sparse. Especially, how the responsible behavior of young individuals can relate to SDGs is something that has recently been debated [16,17]. Therefore, the current study extends the sustainability debate to the perspective of young individuals in the higher education sector of Pakistan.

In Pakistan, the environmental problems have increased every year. Based on the Environmental Performance Index (EPI), Pakistan stands on the 176th position in the list of 180 countries, indicating vulnerable environmental health [18]. Air pollution in many major cities, heavy dust, deforestation, depletion of water resources, and drying up of wetlands and lakes are critical environmental issues in Pakistan. There is no doubt in accepting that many environmental problems require community involvement to prevent a more complex situation and to reduce or solve existing environmental problems.

Primarily, it has been argued that adolescents are more concerned with environmental issues and are more motivated to have a sustainable future than adults $[19,20]$. Today's young generation has been exposed to different environmental challenges like no other generation [21]. Globally, adolescents are raising and originating various social movements to address the environmental challenges, including vulnerable climatic conditions (for example, the movement of Friday for the future [4]). Such social movements on the part of adolescents indicate that today's young generation is concerned about nature. Perhaps this is why adolescents hold moral standards to engage themselves in different environment-specific behaviors. In this regard, university students are a part of the young community and important stakeholders, as they bear the burdens of the past and present indifference to the environment [22]. Likewise, they can be essential stakeholders with better knowledge and education on environmental management issues and the importance of the proper behavior of humans [23]. Therefore, expanding scientific knowledge about what motivates those to behave in an eco-friendly manner is an important area of concern from the perspective of sustainable development.

Recently, contemporary scholars have noticed the importance of corporate social responsibility (CSR) to promote the sustainable behavior of individuals [10,24]. One possible explanation of this surge in the literature on CSR may be that different stakeholders put pressure on enterprises to act in an eco-friendly manner [25]. Specifically, this is attributed to the increased interest of individuals to protect nature [26]. Therefore, one of the objectives of the current analysis is to explain the relationship between CSR and university students' pro-environmental behavior (SPEB) in the higher education sector of Pakistan.

Importantly, studies have established that rational thinking and education are not enough to foster the PEB of individuals, and there is a significant role of emotions to shape such behaviors $[27,28]$. In this regard, contemporary scholars have noted the importance of emotional affinity towards nature (EATN) as a motivational base to spur the PEB of individuals. The studies of Molinario, et al. [29] and DeVille, et al. [30] serve as ready 
examples in this respect. EATN is a dispositional attribute of individuals that explains an individual's emotional connection with nature [31]. Theoretically, it is quite possible to think that the link between CSR activities of an organization (a university is a current case) and SPEB can be better explained in the presence of students' EATN. Hence, another objective of the current study is to test the mediating effect of EATN between CSR and SPEB in the higher education sector of Pakistan.

The proposed framework was employed in the higher education sector of Pakistan. This sector was considered relevant to serve the purpose of the current analysis due to the specific reasons given as follows. In the first place, as the current study intends to explain the PEB among the young generation, considering this sector is logical. Accordingly, the higher education sector constitutes a large number of young students. According to a recent survey, the higher education sector of Pakistan currently holds an umbrella of millions of students [32]. In the second place, the higher education sector of any country represents an audience with better education and advanced knowledge, given that the issues related to the environment have been brought into the academic discussion quite recently. Therefore, it is expected that such an audience can better understand constructs such as PEB, CSR, and EATN. Lastly, as the students spend a significant amount of their daily time at the universities, their environment-specific behavior is of high importance for a country already in vulnerable climatic conditions.

The current analysis enriches the available literature in three ways. Firstly, this study is one of the few studies in which CSR is considered from the perspective of individuals. It is important to mention that much of the previous literature regards CSR to achieve macro-level objectives $[33,34]$. Though there have been recent attempts to link CSR at the individual level, these studies were mostly conducted in a workplace context, such as the link between CSR and employee behavior [35] or employees' performance [36]. The current study is different as it attempts to promote the PEB of university students as an outcome of their university's CSR perceptions. Secondly, even in the context of individuals, the bulk of the literature has focused on adults' environment-specific behavior [4,37], while neglecting the role of young adolescents in improving the environmental footprint of a nation. Thirdly, the current study presents the construct of EATN as a mediator between CSR and SPEB. At the same time, most of the available literature subscribes to establishing a direct link between EATN and PEB [14,32,33]. The remainder of the current work is composed of four parts. The next part deals with the theory and related literature to develop the hypotheses and research framework. Similarly, the methodology part discusses the sample, data collection procedure, and instrumentation. The last two parts are dedicated to results and discussion, respectively. The results part deals with the statistical analysis and outcomes, whereas the discussion part discusses the study results in the light of previous findings. This part also discusses the theoretical and practical implications of the current study.

\section{Theory and Related Literature}

There have been different theories to explain individual behavior. Specifically, scholars have employed the theory of planned behavior (TPB), norm activation theory, social identity theory, stakeholder theory, and protection motivation theory (PMT). All the above theories have been widely used in different studies as a base to explain human behavior. However, the authors feel that PMT is more suitable among the above-stated theories to explain SPEB. The theory was originally proposed by Rogers [38] in his seminal work. Originally, the theory was developed to explain how an individual can behave self-protectively against a perceived health-related risk. However, PMT has been used in diversified areas beyond the health perspectives. More specifically, in recent times, different scholars have applied this theory in the context of environmental management, including climate change $[39,40]$. PMT is a behavioral model that relates to threat-based beliefs and perceptions to realize the importance of health-protective behaviors of individuals. In this respect, threats associated with climate change can lead a person to act pro-environmentally. To explain further, PMT mentions two specific processes that are detrimental to the protective behavior of 
an individual. These processes involve a coping appraisal and a threat appraisal [41,42]. According to the crux of PMT, individuals tend to adopt protective behavior when they encounter a threatening situation, and they believe such a situation can be addressed by taking specific actions. From the perspective of threat appraisal, three antecedents such as maladaptive response reward, the severity of the threat, and susceptibility of threat are central to engaging the individuals in protective behaviors [43]. Maladaptive response rewards relate to the intrinsic and extrinsic benefits of ignoring a protective behavior (PEB in the current sense), whereas severity of threat refers to a belief about the severity of the consequences posed by a threat (environmental dilapidation). Susceptibility of threat refers to one's perception of how a threatening situation can lead a person towards a vulnerable situation.

Likewise, from the perspective of coping appraisal, three antecedents are associated that tend to develop a protective behavior on the part of individuals. These include response-efficacy, self-efficacy, and response cost [43]. Response efficacy is one's belief that a protective behavior (PEB) can significantly mitigate a given threat, whereas selfefficacy relates to one's perception of the ability to perform a required protective behavior. Response-cost relates to one's cost perception associated with a protective behavior. To sum up, an individual tends to engage in protective behaviors when the severity of a threat, susceptibility of threat, response efficacy, and self-efficacy are high, whereas response-cost and maladaptive response rewards are low. Put simply, if an individual is considering whether to buy an eco-friendly vehicle or not in response to environmental issues, they would consider the seriousness of threat given by vulnerable climatic conditions (severity of threat), the degree to which such environmental threat can be personally vulnerable (susceptibility), and if any incentives can benefit a person if climate change was to happen if he did not tend to adopt a protective behavior to mitigate climate risks (maladaptive response reward). Moreover, an individual is also likely to consider whether he is personally capable of switching to an eco-friendly vehicle (self-efficacy), whether he believes that using such a vehicle can mitigate climate risks (response-efficacy), and the response-cost associated with such a purchase.

It has been argued that PMT can better predict adaptive human behavior [44]. Importantly, PMT has been used by different contemporary scholars as a theoretical base to explain the eco-friendly behavior of individuals [45-47]. According to Wang, et al. [48], PMT considers the cost of eco-friendly behavior and focuses on different benefits associated with such behaviors of individuals. Likewise, PMT deals with both the enablers and the barriers towards accepting the environment-specific behavior of individuals. Given that the PMT can explain adaptive environmental behavior, the current study uses this theory as a grounding theory to explain the underlying individual motivation for PEB.

\subsection{CSR and Students' Engagement in PEB}

Although there are many studies on the relationship between CSR and citizen behavior, the literature on CSR and environmental behavior is still lacking. Norton, et al. [49] mentioned that the establishment of policy actions of an enterprise preceded the empowerment of pro-social behavior of employees in a study of 168 permanent employees. Similarly, Wells, et al. [50], conducted a two-level multidisciplinary learning study and demonstrated that the understanding and comprehension of the issues and understanding of relevant information was pertinent to current behavioral satisfaction, job independence, and potential understanding of altered behaviors. Because citizenship behavior is similar to environmental behavior in several ways, discussing the relevant literature on the relationship between CSR and organizational citizenship behavior is an option to understand the underlying mechanism of CSR and PEB [51]. Fu, et al. [52] examined the impact of CSR engagement of an organization on employee attitudes and behaviors, and the results showed that CSR had a positive impact on the citizenship behavior of employees. Similarly, Bozkurt and Bal [53], through an intensive study of staff in pharmacies, FMCG, and the financial sectors, showed the positive relationship between CSR and employees' organizational citizenship 
behavior. Bozkurt and Bal found slight statistical differences between genders in CSR, but found that women were more likely to exhibit expressive behaviors as citizens. Likewise, a study conducted in the telecommunication sector of Pakistan, by Khan, et al. [54], found a positive correlation between CSR and corporate citizenship behaviors of employees.

Contemporary scholars have well noted the importance of CSR to shape individual behavior towards nature. However, much of the literature has discussed this relationship in a business context by focusing on the employees of an organization [55-57]. In the current context, CSR activities of a university have a great potential to promote their eco-friendly behavior. Contemporary students realize that they need to be socially responsible, able citizens for a better and sustainable future. Owing to this, different scholars have explored a positive link between CSR perception of students for their university and their pro-social behavior [58,59]. Social norms have the most significant influence on PEB [60]. In this regard, as there is a congruence between the social norms of an individual and the CSR activities of an organization, CSR can be positively linked to PEB.

Theoretically, the socially responsible behavior of a university can motivate the students to practice such ethical behavior on their part too. Following PMT, the CSR engagement of a university is evaluated by the students for the associated benefits towards society and the environment. Such evaluation on the part of students gives them a justified reason to shape their environment-specific behavior. Moreover, by referring to the norm of reciprocity [61], the CSR activities of a university are considered extra-role engagements (beyond the formal obligations), which are well-observed by the students, and therefore, they want to reciprocate their university positively. All this discussion leads the authors to frame the following hypothesis.

\section{Hypothesis 1 (H1). There exists a positive relationship between CSR and SPEB.}

\subsection{CSR and Emotional Affinity}

In their seminal work, Kals, et al. [31] mentioned that it is not enough to explain the pro-social behavior of individuals by considering the cognitive approach. Instead, the effect of emotions to shape such behaviors can be of the utmost importance. The significance of emotions in environmental studies has been realized since many years ago [62]. However, its full potential was not considered previously. Quite recently, different scholars acknowledged the importance of emotions to shape PEB. For example, the work of Bissing-Olson, et al. [8] was considered as one of the few studies which noticed the importance of individual emotions to shape their PEB. Later on, Rees, et al. [63] also established a positive link between moral emotions and PEB. Quite recently, Zelenski and Desrochers [64] found that individuals' positive emotions serve as the underlying reason to foster the PEB of individuals.

Research on the link between CSR and individual emotions has been receiving rising attention recently. To this end, it has been argued that individuals' positive emotions can turn into a mechanism that can explain the individuals' reaction to an organization's CSR activities [65]. Importantly, it is established that the CSR perception of an organization can serve as an emotional pull on the part of stakeholders, including employees and consumers. In the context of the current study, the CSR activities of an organization can positively be related to and spur EATN. The reason to hold such a view is that CSR focuses on improving the community and the environment [66]. To this end, when individuals observe the CSR commitment of an organization, it raises their affinity towards nature to another level [67].

Similarly, CSR perceptions of individuals can infuse in them a positive feeling towards nature, which can positively impact EATN. Moreover, CSR engagement of an organization can spark this view among the individuals that such an organization has a serious approach to improve society and the environment. All this process is helpful to strengthen the EATN on the part of individuals. From the students' perspectives, when they see the CSR commitment of their university to preserve nature, they also feel an emotional affinity as a result of CSR. Thus, it is quite possible to suggest the following hypothesis. 
Hypothesis 2 (H2). There exists a positive relationship between CSR and EATN.

\subsection{CSR, EATN and SPEB}

In this regard, Kals, et al. [31] were the first to link the concept of EATN to predict the PEB of individuals. Subconsciously, this concept can explain the nature-protective behavior, which is also regarded as PEB or pro-social behavior. Some authors have argued that drawing upon emotional bonds, EATN serves as a base to protect nature. EATN is an emotional attribute that is not easy to elucidate cognitively. Significantly, EATN can be well differentiated from its counterpart, "interest in nature". A positive experience is a necessary precondition for emotional affinity, whereas interest may also trigger from negative experiences. Specifically, a positive experience with nature, for example, exposure to nature, trees, or animals, may be helpful to develop an emotional bond towards nature [68]. Likewise, scholars such as Lyons and Breakwell [69] also acknowledged that exposure to nature, for instance, observing animals, weather, and changing seasons, can create affinity towards nature. The youngster, especially in the collective cultures (as in the current case), is accompanied by their parents and other family members who transmit their nature-related values to them. It is quite possible that these transmitted nature-related values may stay in the adolescents at a later age, implying that EATN may serve as an enabler to infuse a nature-protective behavior in the adolescents.

Studies have also established that CSR activities of an organization can generate positive emotions among stakeholders, including employees [70,71] and consumers [72,73]. The mere explanation for such positive emotions due to CSR engagement of an organization lies in the fact that CSR activities of an organization are usually considered as steps to create long-term benefits for the community and the environment. When employees or consumers observe such social steps of an organization, they develop positive emotions. Studies have also shown that positive emotions among employees and consumers for a socially responsible organization create an emotional bond in them to favor such organizations [74,75]. In the same vein, such arguments may also hold in the case of university students. The presence of EATN between the general relation of CSR and PEB may provide an added explanation for such a relationship. Therefore, the authors propose the following hypotheses.

Hypothesis 3 (H3). There exists a positive relationship between EATN and SPEB.

Hypothesis 4 (H4). EATN mediates the relationship between CSR and SPEB.

Table 1 presents a brief of different previous studies in the field of CSR and higher education, and what the knowledge gaps were in these studies. The hypothesized model of the current research is presented in Figure 1.

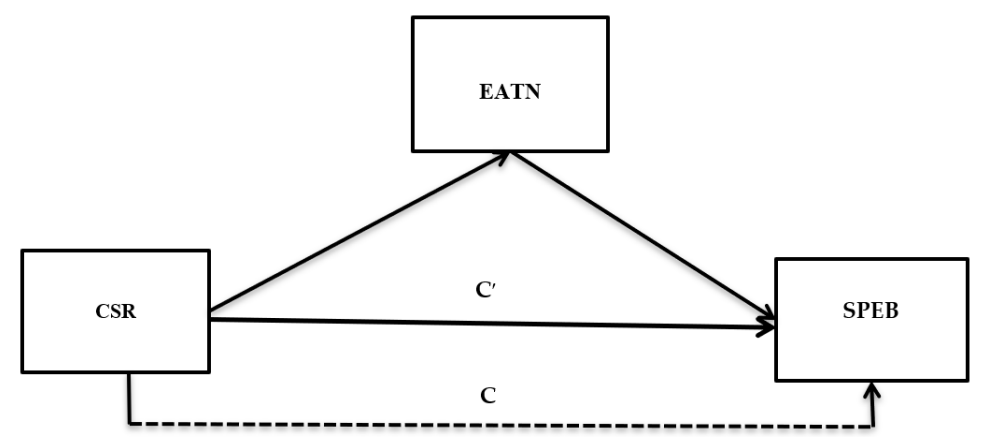

Figure 1. Research model of the current analysis: corporate social responsibility $-\mathrm{CSR}=$ the predictor variable, SPEB-Student's pro-environmental behavior = the criterion variable, EATN-Students' emotional affinity = the intervening variable, $C=$ the effect of the predictor on the criterion in the absence of mediator, $\mathrm{C}^{\prime}=$ effect of the predictor on the criterion in the presence of the mediator. 
Table 1. Different studies on CSR with contributions, and knowledge gaps.

\begin{tabular}{ll}
\hline Authors & Findings \\
\hline Shah, et al. [76] & $\begin{array}{l}\text { The study confirmed the positive relationship between CSR } \\
\text { perception of employees and PEB with two mediators }\end{array}$
\end{tabular}

Islam, et al. [1]

Suganthi [77]

Gkorezis and Petridou [25]

Akhtar, et al. [78]

Dahan and Senol [79]

Rahman, et al. [80]

Galvão, et al. [81]

Binsawad [82]

Chan and Mohd Hasan [83]
The authors found that there exists a positive link between CSR and PEB with the moderating role of empathy

The study documents the potential role of CSR to predict the environment-specific behavior of employees with the mediating effect of green practices

The study postulates that CSR from a micro perspective can lead the employees to adopt PEB. The study also considered organizational identification as a mediator.

The authors considered the higher education sector to better shape the PEB of students and teachers from the perceptive of ability, motivation, and opportunity.

The study acknowledged the potential role of CSR to build a good reputation of a university and to find a good competitive position of a university

The study highlights the importance of CSR for the higher education sector and different paths that can lead an educational institute to adopt CSR.

The study produces significant evidence that different factors contribute towards the CSR orientation of university student

The authors assume CSR from a marketing perspective to earn a competitive position in the current volatile environment

The authors explored different CSR practices in the higher education sector from the perspective of employees

Knowledge Gap

The authors employed stakeholder theory which only considers the direct stakeholders while neglecting the larger aspect of CSR for general society and environment.

While the study considered the logical role of CSR to shape the PEB of employees, the study was conducted in a business context, and could not highlight the importance of sustainability for every individual

The study could not consider the potential role of CSR to shape the behavior of individuals in a non-business context. Also, the study mentions different theories, however, fails to mention the broader aspect of theory to support their argument from the perspective of CSR

Though the study acknowledges the potential role of CSR at a micro-level, however, it only included employees as stakeholders and neglected other stakeholders.

Though the hypothesized model was logical, however, it could not consider the potential role of CSR in the higher education sector to influence the PEB of students.

The study assumes CSR from a reputational approach, however, it did not consider the broader aspect of CSR, especially from the perspective of sustainability

The study considers different factors that pressurize an institution to practice CSR. The study documents CSR from a defensive perspective. However, it could not portray CSR as a proactive strategy. Moreover, what could be the potential benefits of CSR was not clearly mentioned.

The authors did not consider how CSR can motivate the students to act pro-environmentally.

Though looking at CSR from the perspective of marketing is very important, however, such a perspective did not consider the importance of CSR from the perspective of sustainability in the higher education sector.

Although the study considered different organizational factors, however personal factors to shape the behavior of employees were not considered

\section{Methodology}

\subsection{Sample and Data Collection Procedure}

Currently, Pakistan is the sixth most populous nation globally, with a population of more than 210 million. Pakistan is known for having the highest population growth rate. While the growth rate of two percent has slowed due to several interventions taken on the part of the government to reduce the fertility rate, the population is still projected to reach 403 million by 2050 [84]. The young generation in the country shares the most significant portion of the total population. Approximately $64 \%$ of Pakistan's population is under 30 years old [85]. Moreover, the median age in Pakistan is 22.8 [86].

There is a proven role of education, specifically higher education, for the development of any nation in the world. Higher educational institutes impart advanced knowledge to adolescents and spur their skills to enable them to shoulder the future responsibility for efficient management of a country [87]. In this regard, at the time of independence (1947), Pakistan had only one university (University of the Punjab), located in Lahore with an enrollment of 644 students. Over time, the ensuing years were followed by the expansion of universities, including Quaid-Azam university in Islamabad, which was founded in 1967. The first private university, Lahore University of Management Sciences, was established in 1984, followed by Aga Khan University in 1985. The first major expansion of several large state universities took place during 1971-1977 [88]. Higher education in Pakistan means education above grade 12 . The higher education sector in the country includes 
universities, affiliated colleges, and degree-awarding institutes. The higher education commission (HEC) is the main regulating body that regulates this sector in the country, which was established in 2002. Moreover, along with different public sector institutes, the higher education sector of Pakistan also includes a large number of private universities and degree-awarding institutes.

The cities such as Lahore, Karachi, and Islamabad are the educational hub in the country. However, the current study only considered Lahore and Karachi in the collection of data. The reason for considering these two cities lies in the fact that both of these cities are currently facing vulnerable climatic conditions, which is a major public health risk for the multi-million population of these two cities. Equally essential to mention here is that both of these cities have been on the list of the most polluted cities globally. Especially, Lahore was declared the most polluted city in the world last year [89]. On a further note, as both Lahore and Karachi hold the largest umbrella of public and private higher educational institutes, considering these two cities to serve the purpose of the current survey is logical.

The current survey included both the public sector universities and the private sector universities for the sake of data collection. In this regard, before formally approaching a university, the authors confirmed the CSR participation of such universities. For this purpose, the authors searched the related information on the webpage of the university. Moreover, such information was also gathered by paying personal visits. After identifying such universities, the authors formally contacted the concerned departments of the potential universities to allow the authors to collect the data from students. A total of eight large universities responded positively, including two public sector universities and six private sector universities from Karachi and Lahore.

The survey instrument of the current study was a questionnaire that was adapted from different reliable sources. Before making the survey instrument visible to the respondents, the authors validated the suitability of the questionnaire items. For this purpose, the authors requested that experts in the field assess the suitability and appropriateness of the questionnaire to serve the objectives of the current survey. After receiving a positive assessment from the experts, the questionnaire was made available to the respondent. This step to validate the question items is in line with the recommendation of the previous researchers $[90,91]$. The authors also followed the ethical protocols given in the Helsinki declaration [92]. In this regard, the sampled students were assured of their anonymity by the authors. Moreover, every student was given an equal opportunity to quit the survey at any stage without specifying a reason to the authors if he or she was uncomfortable in answering the survey questions. Lastly, each participant also provided informed consent for their voluntary willingness to respond to the current survey. The questionnaire was distributed among a representative sample of students between the ages of 17-30 years. The authors distributed a total of 1000 questionnaires among different students randomly. Eventually, 656 valid responses were received back, implying a response rate close to $66 \%$.

\subsection{Measures}

The authors considered the already published source of scales to operationalize different constructs of the current study (CSR, SPEB, and EATN). The primary reason for considering such published scales was that they have their pre-established reliability and validity, as mentioned by different scholars $[18,68,80]$. In this respect, the construct of CSR was operationalized by adapting a six-item scale from the study of Turker [93]. Perhaps this is one of the most widely used scales to operationalize the CSR construct from the perspective of individuals. This is why a plethora of studies have employed this scale $[29,48,82]$. In the current context, scholars have also employed this scale in university settings. For example, Droms Hatch and Stephen [94] employed this scale to measure the CSR perception of university students of the Midwest (USA).

Similarly, Nejati and Nejati [95] also used the same in the context of Malaysian universities. A sample item of this scale was "our university participates in activities which 
aim to protect and improve the quality of the natural environment". The scale of SPEB was operationalized by using the source of Robertson and Barling [96]. This scale was composed of seven items. A sample item was "I turn lights off when not in use." Lastly, the scale of EATN was adapted from Müller, et al. [97], who modified this scale, which was initially developed by Kals, et al. [31]. There were a total of 10 items on this modified scale. A sample item of this scale was "when I spend time in Nature I feel free and easy". This modified version was also used in a recent study by Ito, et al. [98]. The data were collected during September 2020 and December 2020.

A five-point Likert scale was employed to record the responses of the respondents. The demographic detail of the surveyed students is given in Table 2 .

Table 2. Demographic profile of respondents $(n=656)$.

\begin{tabular}{lll}
\hline & Frequency & $\%$ \\
\hline Gender & 382 & 58.23 \\
Male & 274 & 41.77 \\
Female & & \\
Age & 110 & 16.77 \\
$17-20$ & 276 & 42.07 \\
$21-24$ & 188 & 23.63 \\
$25-28$ & 82 & 12.50 \\
Above 28 & & \\
Level of Education & 284 & 43.29 \\
Undergraduate & 372 & 56.70 \\
Graduate & & \\
\hline
\end{tabular}

\subsection{Common Method Variance}

Common method variance (CMV) is a commonly reported issue in survey research design. Especially, the potential risk of CMV is more evident in surveys where a single data collection source is used. For example, collecting all the information (including independent, mediating, and dependent variables) from the same individuals [99]. Due to the presence of $\mathrm{CMV}$ in a dataset, there is a strong likelihood for false internal consistency. Indeed, the presence of CMV causes variations in the responses not because of the changes in perception of the respondents, but due to a biased instrument [100]. Thus, the presence of such an issue can lead an analyst to draw misleading results, making the whole research effort invalid. Given that the current study used the same student to collect the information for all constructs, there is a possibility that the potential issue of CMV may exist. Therefore, before continuing further in the data analysis phase, the authors were convinced to confirm the absence of CMV. A common approach to decide whether the potential threat of CMV exists in a dataset is employing a single factor analysis as proposed by Harman [101]. For this, the authors allowed all the survey items to be loaded onto a single factor by using IBM-SPSS software. In this regard, the authors did not consider any rotation method. Rather, the number of factors was restricted to " 1 ". The authors then assessed the output of this analysis (Table 3) for the presence of CMV. The standard guideline in this concern is that if the result of a single factor analysis indicates that there is the existence of a single dominant factor that explains $50 \%$ or more of the total variance, it is an indication that CMV exists in a dataset. The current analysis revealed that there is no such dominant factor that explains such a sheer amount of total variation (more than 50\%). All this implies that there is no serious concern in the dataset of the current study to address a CMV issue.

Though the single factor analysis results detected no CMV issue, to further verify, the authors also performed a one-factor confirmatory analysis in AMOS. This time, the above-explained process was repeated but in the context of confirmatory factor analysis (CFA). The results of a single CFA again confirmed that there is no significant CMV issue that needs action on the part of the authors. The model fit indices generated poor values, implying that there is poor fit between the actual theoretical models (three-factor mediated 
model $)$ and one-factor model $\left(\chi^{2}=2246.886, d f=341, \chi^{2} / d f=6.589\right.$, RMSEA $=0.096$, $\mathrm{CFI}=0.39$, NFI $=0.44$ ).

Table 3. Total variance explained by a single factor.

\begin{tabular}{|c|c|c|c|c|c|c|}
\hline \multirow{2}{*}{ Factor } & \multicolumn{3}{|c|}{ Initial Eigenvalues } & \multicolumn{3}{|c|}{ Extraction Sums of Squared Loadings } \\
\hline & Total & $\%$ of Variance & Cumulative \% & Total & $\%$ of Variance & Cumulative $\%$ \\
\hline 1 & 6.938 & 30.164 & 30.164 & 6.312 & 27.441 & 27.441 \\
\hline 2 & 2.992 & 13.011 & 43.174 & & & \\
\hline 3 & 2.220 & 9.651 & 52.825 & & & \\
\hline 4 & 1.134 & 4.930 & 57.755 & & & \\
\hline 5 & 0.995 & 4.328 & 62.083 & & & \\
\hline 6 & 0.900 & 3.912 & 65.995 & & & \\
\hline 7 & 0.856 & 3.721 & 69.716 & & & \\
\hline 8 & 0.708 & 3.076 & 72.792 & & & \\
\hline 9 & 0.668 & 2.902 & 75.694 & & & \\
\hline 10 & 0.627 & 2.724 & 78.418 & & & \\
\hline 11 & 0.606 & 2.636 & 81.055 & & & \\
\hline 12 & 0.533 & 2.316 & 83.370 & & & \\
\hline 13 & 0.505 & 2.197 & 85.568 & & & \\
\hline 14 & 0.487 & 2.119 & 87.686 & & & \\
\hline 15 & 0.453 & 1.968 & 89.654 & & & \\
\hline 16 & 0.425 & 1.848 & 91.502 & & & \\
\hline 17 & 0.383 & 1.664 & 93.166 & & & \\
\hline 18 & 0.324 & 1.411 & 94.576 & & & \\
\hline 19 & 0.300 & 1.304 & 95.880 & & & \\
\hline 20 & 0.287 & 1.250 & 97.130 & & & \\
\hline 21 & 0.241 & 1.047 & 98.177 & & & \\
\hline 22 & 0.224 & 0.975 & 99.152 & & & \\
\hline 23 & 0.195 & 0.848 & 100.000 & & & \\
\hline
\end{tabular}

Note: Extraction Method: Principal Axis Factoring.

\section{Results}

\subsection{Construct Evaluation: Factor Loadings, Validity, and the Reliability}

The absence of CMV in the dataset of the current survey led the authors toward the further stages in the data analysis. Hence, the authors performed construct evaluation for all three constructs in this survey. For this, the authors carried out different statistical tests, including assessing factor loadings through factor analysis, validity analysis through different values of average variance extracted (AVE), and reliability analysis. To begin with, the authors performed a factor analysis to assess if there was an issue with the factor loadings of any item (such as poor factor loadings or cross-loadings, etc.). The results of the factor analysis are shown in Table 4 . As per the results given in Table 4, no item's loading is below the standard criterion of $\lambda>0.5$, implying that all the items are well loaded on to their respective factors. The item loadings ranged between 0.71-0.94. Moreover, the authors also tested the convergent validity of each construct. To achieve this, the AVE for each construct was calculated by employing the formula given in Equation (1)

$$
\mathrm{A} . \mathrm{V} . \mathrm{E}=\frac{\sum_{i=1}^{k} \lambda_{i}^{2}}{\sum_{i=1}^{k} \lambda_{i}^{2}+\sum_{i=1}^{k} \cdot \operatorname{var}(\varepsilon \mathrm{i})}
$$

Formally, the authors followed the recommendations of Fornell and Larcker [102] to judge the candidature of each construct for convergent validity. In this respect, if the value of AVE for a construct under investigation is beyond 0.5, it is established that the convergent validity for that construct is appropriate. In this regard, the values for all three constructs (CSR - 0.657, EATN—0.654, SPEB-0.596) were above 0.5 . This process indicates that the convergent validity in each case is well established. These guidelines to validate a construct can also be seen in the seminal work of Gefen, et al. [103]. 
Table 4. Factor loadings, convergent validity, and composite reliability.

\begin{tabular}{cccccccc}
\hline Item & $\lambda$ & $\lambda^{2}$ & E-Variance & $\sum \lambda^{2}$ & Items & AVE & CR \\
\hline CSR1 & 0.84 & 0.71 & 0.29 & & & & \\
CSR2 & 0.78 & 0.61 & 0.39 & & & & \\
CSR3 & 0.91 & 0.83 & 0.17 & & & & \\
CSR4 & 0.77 & 0.59 & 0.41 & & & & \\
CSR5 & 0.72 & 0.52 & 0.48 & & & \\
CSR6 & 0.83 & 0.69 & 0.311 & 3.942 & 6 & & \\
EATN1 & 0.74 & 0.55 & 0.45 & & & & \\
EATN2 & 0.88 & 0.77 & 0.27 & & & & \\
EATN3 & 0.79 & 0.62 & 0.38 & & & & \\
EATN4 & 0.73 & 0.53 & 0.47 & & & & \\
EATN5 & 0.73 & 0.53 & 0.47 & & & & \\
EATN6 & 0.94 & 0.88 & 0.12 & & & & \\
EATN7 & 0.78 & 0.61 & 0.39 & & & \\
EATN8 & 0.77 & 0.59 & 0.41 & & & \\
EATN9 & 0.86 & 0.74 & 0.26 & & & \\
EATN10 & 0.84 & 0.71 & 0.29 & 6.542 & 10 & & \\
SPEB1 & 0.74 & 0.55 & 0.45 & & & & \\
SPEB2 & 0.71 & 0.50 & 0.50 & & & & \\
SPEB3 & 0.75 & 0.56 & 0.44 & & & & \\
SPEB4 & 0.73 & 0.53 & 0.47 & & & & \\
SPEB5 & 0.87 & 0.76 & 0.24 & & & & \\
SPEB6 & 0.82 & 0.67 & 0.33 & & & \\
SPEB7 & 0.77 & 0.59 & 0.41 & 4.169 & 7 & \\
\hline
\end{tabular}

Notes: $\lambda=$ Item loadings, C.R $=$ composite reliability, $\sum \lambda^{2}=$ sum of square of item loadings, E-Variance = error variance.

Lastly, the authors also evaluated the composite reliability for each construct by employing the formula given in Equation (2).

$$
\text { Composite reliability }=\left(\left(\sum \lambda \mathrm{i}\right) 2\right) /\left(\sum \lambda \mathrm{i}\right) 2+\sum \operatorname{var}(\varepsilon \mathrm{i})
$$

In this regard, the value of composite reliability beyond 0.7 is considered significant to establish the composite reliability of a construct. The results of composite reliability for each construct have also been reported in Table 3 for the convenience of the readers (CSR-0.920, EATN—0.949, SPEB-0.911).

In the next phase of the data analysis, the authors performed a correlation analysis to assess the value and nature of the relationship between different pairs of constructs. These results can be seen in Table 5. According to such results, the correlation is positive in all cases, which is an indication of the acceptance of the hypotheses of the current study. As a case, it can be observed that the value of correlation between CSR and SPEB is $r=0.428$, which is positive and significant, establishing that both of these constructs have positive relationships with each other. The same kind of association can be seen between other pairs in Table 5.

Table 5. Correlation, discriminant validity, and model fit indices.

\begin{tabular}{llll}
\hline Construct & CSR & EATN & SPEB \\
\hline CSR & 0.886 & $0.382^{* *}$ & $0.428^{* *}$ \\
EATN & & 0.928 & $0.349^{* *}$ \\
SPEB & & 0.917 \\
Mean & 3.77 & 3.89 & 4.02 \\
SD & 0.62 & 0.60 & 0.49 \\
MSV & 0.18 & 0.15 & 0.18 \\
ASV & 0.16 & 0.13 & 0.15 \\
Sqrt (A.V.E) & 0.81 & 0.81 & 0.77
\end{tabular}

Notes: $\mathrm{SD}=$ standard deviation, ${ }^{* *}=$ significant values of correlation, diagonal values $=$ Cronbach alpha, maximum shared variance $=\mathrm{MSV}$, and average shared variance $=\mathrm{ASV}$. 
Meanwhile, in order to validate the discriminant validity, the authors checked with the two tests. Firstly, the authors calculated the maximum shared variance (MSV) values and average shared variance (ASV) for each construct. The standard rule here is that if both values (MSV and ASV) are less than the value of AVE for the same construct, then the condition for discriminant validity is fulfilled. In the current case, the values of MSV and ASV in each case are less than AVE (for a case, AVE for CSR-0.657, MSV-0.18, and ASV-0.16). Yet, to a further level, the authors also calculated the square root value for each AVE and then compared it to the correlation values. The general rule is that if the square root of AVE for a construct is greater than the correlation values, then discriminant validity is confirmed. In this regard, the square root value of AVE for CSR is 0.81, greater than the correlational values in comparison (0.382 and 0.428).

Lastly, the authors also evaluated different alternate models against the actual measured model of the current study. These results have been reported in Table 6. In doing so, the authors developed different alternate models, for example, model 1 was the singlefactor model, model 2 was a two-factor model, and model 3 was a three-factor model (the actual theorized model). The results showed that the three-factor model produced the most significant results $\left(\chi^{2}=21,807.259, d f=623, \chi^{2} / d f=2.91\right.$, RMSEA $=0.047, \mathrm{CFI}=0.92$, $\mathrm{NFI}=0.92)$. For instance, the normal range of $\chi^{2} / d f$ is considered less than five; ideally, it should be less than three. Moreover, for both the comparative fit index (CFI) and normed fit index (NFI), values should also be greater than 0.90 , and lastly, the value of root means square of error approximation (RMSEA) should be less than 0.08 .

Table 6. Model fit comparison, alternate vs. hypothesized models.

\begin{tabular}{llll}
\hline & Model-1 & Model-2 & Model-3 \\
\hline$\chi^{2}(d f)$ & $2246.886(341)$ & $2127.533(446)$ & $1807.259(623)$ \\
$\chi^{2} / d f$ & 6.59 & 4.77 & 2.91 \\
NFI & 0.39 & 0.61 & 0.92 \\
CFI & 0.44 & 0.68 & 0.92 \\
RMSEA & 0.096 & 0.059 & 0.047 \\
\hline
\end{tabular}

\subsection{Hypotheses Validation}

In the last data analysis phase, the authors validated the study's hypotheses by employing structural equation modeling (SEM). The SEM analysis was completed in two stages. In the first stage, a structural model was developed to test the direct association of the hypotheses (H1, H2, and H3) without considering any mediation effect of EATN. Such results can be seen in Table 7. As per these results, the first three hypotheses (H1, H2, and H3) were statistically proven $(\beta 1, \beta 2$, and $\beta 3$ were $0.399,0.361$, and 0.336 with $p<0.05$ ). Therefore, H1, H2, and $\mathrm{H} 3$ are accepted.

Table 7. The results for hypotheses $\mathrm{H} 1, \mathrm{H} 2$, and $\mathrm{H} 3$.

\begin{tabular}{ccccccccc}
\hline \multicolumn{1}{c}{ Path } & Relation & Estimates & SE & CR & $p$-Value & ULCI & LLCI & Decision \\
\hline CSR $\rightarrow$ SPEB & + & $(\beta 1) 0.399^{* *}$ & 0.045 & 8.87 & $* * *$ & 0.368 & 0.311 & Accepted \\
CSR $\rightarrow$ EATN & + & $(\beta 2) 0.361^{* *}$ & 0.033 & 10.94 & $* * *$ & 0.412 & 0.365 & Accepted \\
EATN $\rightarrow$ SPEB & + & $(\beta 3) 0.336^{* *}$ & 0.049 & 6.86 & $* * *$ & 0.238 & 0.211 & Accepted \\
\hline
\end{tabular}

Notes: ULCI $=$ upper-limit confidence interval, LLCI $=$ lower-limit confidence interval, ${ }^{* *},{ }^{* * *}=$ significant values.

After validating the structural model for direct relationships ( $\mathrm{H} 1, \mathrm{H} 2$, and $\mathrm{H} 3$ ), the authors tested the mediation results (H4). For this purpose, the previous structural model was modified and, this time, the EATN was included as a mediator in the structural model. Moreover, the bootstrapping option was also employed to confirm the mediation effect of EATN. For this, a large bootstrapping sample of 2000 was considered by the authors. Using this large bootstrapping sample is also recommended in several studies [18,93,94]. Such results have been reported by the authors in Table 8 . According to the results, there is 
confirmation that EATN acts as a partial mediator between CSR and SPEB. Nevertheless, $\beta 4$ was 0.121 , which indicated that EATN positively mediates the relationship between CSR and SPEB. Moreover, this mediation effect significantly explained almost $30 \%$ variation in SPEB, implying that $\mathrm{H} 4$ is also accepted. The hypothesized structural model is shown in Figure 2.

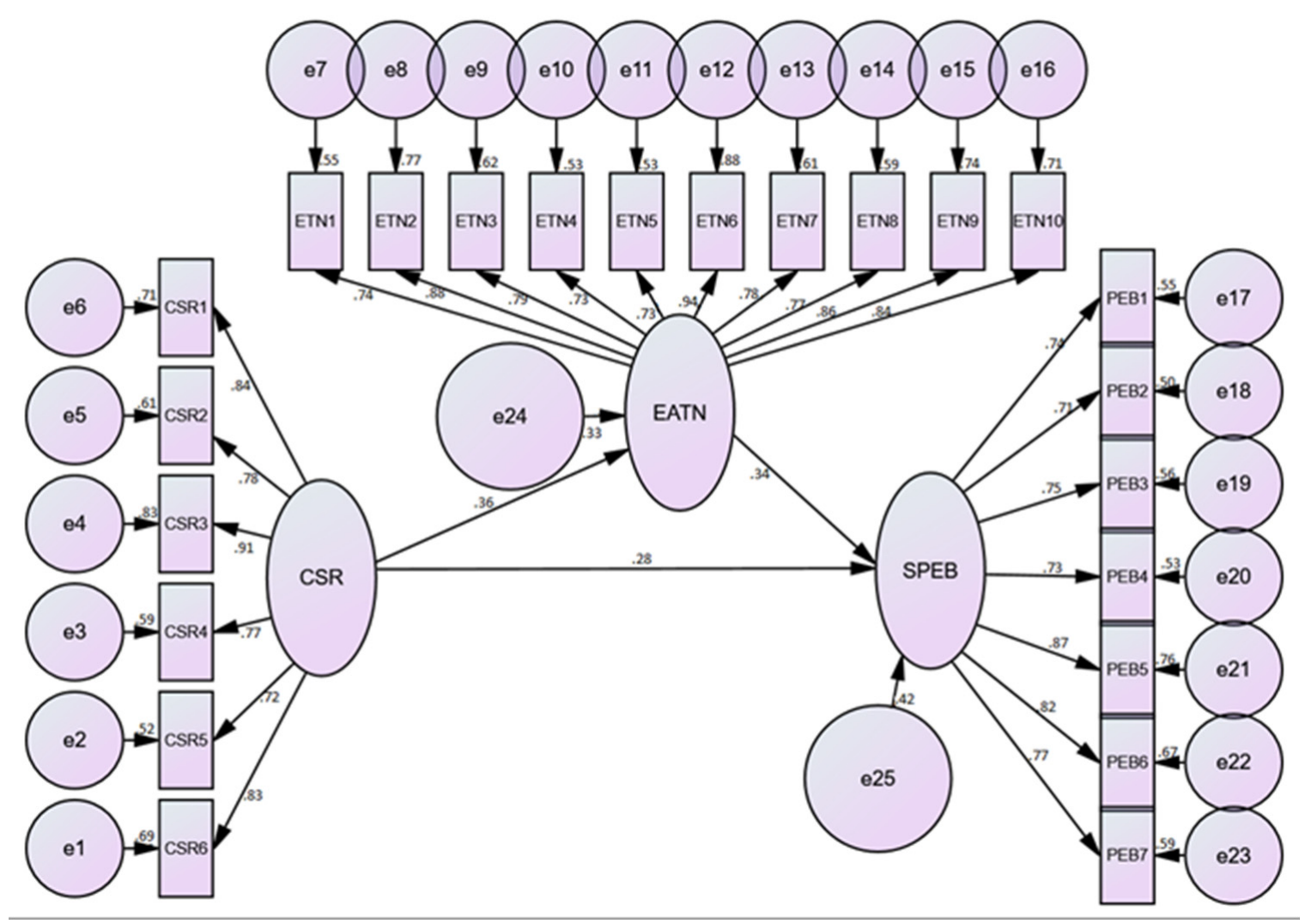

Figure 2. Hypothesized structural model with standardized estimates.

Table 8. Mediation results for H4.

\begin{tabular}{|c|c|c|c|c|c|c|c|c|}
\hline Path & Relation & Estimates & SE & Z-Score & $p$-Value & ULCI & LLCI & Decision \\
\hline $\mathrm{CSR} \rightarrow \mathrm{EATN} \rightarrow \mathrm{SPEB}$ & + & ( $\beta 4) 0.121 * *$ & 0.022 & 5.50 & $* * *$ & 0.189 & 0.117 & Accepted \\
\hline Total effect & & 0.399 & & & & & & \\
\hline Indirect effect & & 0.121 & & & & & & \\
\hline Direct effect & & 0.278 & & & & & & \\
\hline Proportion of mediation & & 0.303 & & & & & & \\
\hline
\end{tabular}

Notes: ULCI $=$ upper-limit confidence interval, $\mathrm{LLCI}=$ lower-limit confidence interval, ${ }^{* *},{ }^{* * *}=$ significant values, $\mathrm{S} . \mathrm{E}=$ standard error.

\section{Discussion}

The current study was carried out to serve some specific objectives. One of the basic objectives was to investigate the relationship of CSR perception of students about a university and their PEB. To this end, the empirical findings of the current study validated a positive association between CSR and SPEB. In most of the prior studies, it was supported that there exists a positive relationship between CSR and PEB in an industrial context. However, research on such a relationship in the context of university students is sparse. Given that the students spend a significant amount of their daily time in a university, it was important to investigate such a relationship, especially for a country confronted with extreme climatic conditions. Altogether, it was realized from the statistical findings that CSR engagement of a university can infuse a sense of care in the students, which improves their environmental behavior. 
Moreover, investigating such a relationship in adolescents is of the utmost importance for a country that still has a median age of less than 23 years and where more than $60 \%$ of the population is below 30 years. The findings of the current study may be helpful for the higher education sector of Pakistan to improve the country's environmental footprint through promoting the PEB among its students as a result of CSR. The previous studies have also supported the current argument; however, as stated earlier, the context of such studies was workplaces. In this regard, one can see some recent studies of Afsar and Umrani [104] and Raza, et al. [105]. Moreover, in the context of the higher education sector, the study of Bhattacharyya, et al. [106] is a reasonable match with the theme of the current survey.

Another objective of the current study was to investigate the importance of emotions to shape the PEB in the context of the higher education sector of Pakistan. Given that rational thinking and education are not enough to foster the PEB of individuals, as there is a significant role of emotions in shaping such behaviors $[27,28]$, the current study investigated the mediating effect of EATN of students between the relationship of CSR and SPEB. In this respect, the results confirmed that EATN significantly mediates (more than $30 \%$ ) between CSR and SPEB. Specifically, the results favored that EATN is a partial mediator in the above relationship, implying that the general relationship of CSR and SPEB still exists; however, when it is explained through the emotions (EATN), the relationship becomes more prominent. Previous studies have also noted the importance of emotions to spur the discretionary behavior of individuals [64,107]. Even, in line with the current context, some scholars have also mentioned the importance of EATN to predict the environmentspecific behavior of adolescents [19,97]. Also, following PMT, such results can be better explained. This theory suggests that an individual tends to be engaged in adaptive responses (PEB in the current context) when he or she encounters any threatening situation, which he or she believes is due to the lack of proper action. This lack of proper action can pose a threat to the individual. This theory is advantageous to provide a logical base for PEB among university students in the current context. For example, by realizing the threat of extreme climatic conditions, one can justify his engagement in different environmentspecific behaviors. Thus, the current study successfully achieved both of its major objectives and validated that CSR and SPEB have a positive association, whereas EATN mediates this relationship.

\subsection{Implications for Theory}

The current study has some important implications for the existing literature on environmental management, CSR, and human psychology. In this regard, this analysis adds to the available environmental management literature from the perspective of adolescents such as university students, which was not well-explored previously. Given that much of the research has been conducted to investigate the PEB of adults [37,108], the current study enriches the existing literature from the young generation's perspective. Likewise, much of the research has paid less attention to investigating PEB in a non-business context. The current study attempts to fill this literature gap by considering the university students (non-business context). Since there are millions of youth that exist in the higher education sector of Pakistan, the current study is an essential addition to the available literature. In the same vein, most of the CSR studies in the previous literature were conducted at the organizational level $[109,110]$. However, its potential to shape individual behavior was just recently realized. Nevertheless, there are limited studies in this domain, indicating the importance of conducting more studies. Last but not least, the current study presented the construct of EATN as a mediator between CSR and SPEB. To this end, most of the available literature presents EATN as a direct predictor of PEB [14,32,33].

\subsection{Implications for Practice}

The current study offers some important practical implications, especially for the higher education sector of Pakistan. To begin with, the current study offers a unique insight 
for the management of universities in the country to improve the environmental footprint of Pakistan through the students. This implication has a special meaning for a country with a younger generation that is currently a mere victim of climate change vulnerability. It is important to mention that environmental responsibility belongs to everyone, and the view that such responsibility only belongs to industries is misleading. Every sector has to realize its role in the environment, and the universities can significantly contribute to reducing the environmental dilapidation in the country. Similarly, the universities in Pakistan must reconsider their CSR approach. Currently, most universities have a CSR framework that originated in philanthropic orientation (for example, waiving the tuition fee of a poor student, providing free-of-cost hostel accommodation to the deprived students, etc.). This is the time to re-strategize the approach towards CSR from the perspective of environmental management. In this regard, the universities must realize that positive CSR perceptions of a university for the environment are helpful in improving the environmental behavior of students, which in turn reduces the overall environmental footprint of a university. Quite recently, some universities in Pakistan have taken sustainability-related initiatives. For example, the University of Central Punjab (UCP) in Lahore has made a significant attempt to improve its environmental footprint by installing a solar energy system. In a similar manner, the DHA Suffa University in Karachi has established its sustainability secretariat, which actively engages its students in different CSR-related activities. However, given that this secretariat is still pro-philanthropic, there is a need to improve its engagement from the perspective of the environment.

On a further note, as this study shows that EATN is a significant mediator to predict SPEB, it is proposed that universities organize such programs that aim to increase students' exposure to nature. For example, universities may formally give a place, into their academic colanders, for students to tour different places rich with the natural environment (especially the northern areas of the country). Finally, to achieve a sustainable future in the country, it is important to promote sustainable behavior among university students, as such behaviors improve the environmental footprint of a university but are also helpful for the students when they join different industries after completing their studies education.

\subsection{Limitations and Future Research Directions}

Even though the current analysis discusses some critical implications for the higher education sector of Pakistan, the study still encounters some limitations. First of all, the study sample was only limited to Lahore and Karachi. Thus, the geographic concentration may limit the generalizability of the current analysis. In this respect, future researchers are required to include more cities and provinces to make a better and generalizable impact. Second, the study only records the perceptual measures of CSR. Though such perceptual measures are helpful in a plethora of studies, using an objective measure of such constructs in the upcoming studies may generate more realistic outcomes.

Similarly, the current study's findings may remain limited in their scope because a cross-sectional survey design was employed, limiting the causality of association among different constructs. In this regard, a better approach in future studies may be to incorporate a longitudinal data design. Given that CSR is context and culturally specific, the current survey findings may remain similar for the like cultures (India, Bangladesh, etc.). However, in different cultures, due care is necessary before interpreting the current survey results. Lastly, the current study only included university students in different public and private universities of Pakistan. However, they only constitute a part of the younger generation. Therefore, in future studies, students from other institutes such as colleges may also be included to give a better representation.

\section{Conclusions}

The current study is one of the limited studies that attempt to employ CSR from the perspective of the environment. More specifically, the current study considered the younger generation of Pakistan in a non-business context. The empirical findings of this survey 
may help policymakers of higher education realize the importance of CSR to improve a university's environmental footprint by promoting the SPEB. Importantly, the study highlights that environmental effort is the responsibility of every individual. Moreover, if a nation wants to have a sustainable future, it must promote sustainability at the level of the individual. Likewise, the current study has the potential to raise the importance of sustainability from the perspective of SDGs. Given that the sustainable practices at the level of individuals can significantly improve the environmental quality, as indicated in the recent global emission report by the UN, the CSR orientation of an institute can provide further support to attain a sustainability perspective in line with SDGs. In this vein, Pakistan can observe the sustainability efforts of EU nations, where most of the countries have set an example for the entire world by improving the sustainability index. Among many other reasons, the success story of such a nation also lies in improving sustainability awareness at the level of individuals. Therefore, if Pakistan has to achieve a sustainable future, contribution on the part of individuals is a way forward.

Author Contributions: All of the authors (G.J., G.Y. and I.S.) contributed to conceptualization, formal analysis, investigation, methodology, and writing and editing of the original draft. All authors have read and agreed to the published version of the manuscript.

Funding: This research received no external funding.

Institutional Review Board Statement: Not applicable.

Informed Consent Statement: Informed consent was obtained from all subjects involved in the study.

Data Availability Statement: The data will be made available by contacting the corresponding author on a reasonable request.

Conflicts of Interest: The authors declare no conflict of interest.

$\begin{array}{ll}\text { Abbreviations } \\ \text { CSR } & \text { corporate social responsibility } \\ \text { SDGs } & \text { Sustainable development goals } \\ \text { SPEB } & \text { student's pro-environmental behavior } \\ \text { EATN } & \text { emotional affinity towards nature } \\ \text { AVE } & \text { average variance extracted } \\ \text { NFI } & \text { normed fit index } \\ \text { CFI } & \text { comparative fit index } \\ \text { RMSEA } & \text { root means square of error approximation } \\ \text { MSV } & \text { maximum shared variance } \\ \text { ASV } & \text { average shared variance } \\ \text { SEM } & \text { structural equation modeling } \\ \text { S.D } & \text { standard deviation } \\ \chi^{2} & \text { chi-square } \\ d f & \text { degree of freedom }\end{array}$

\section{References}

1. Islam, T.; Ali, G.; Asad, H. Environmental CSR and pro-environmental behaviors to reduce environmental dilapidation. Manag. Res. Rev. 2019, 42, 332-351. [CrossRef]

2. Shafiei, A.; Maleksaeidi, H. Pro-environmental behavior of university students: Application of protection motivation theory. Glob. Ecol. Conserv. 2020, 22, e00908. [CrossRef]

3. Islam, M.; Managi, S. Green growth and pro-environmental behavior: Sustainable resource management using natural capital accounting in India. Resour. Conserv. Recycl. 2019, 145, 126-138. [CrossRef]

4. Balundè, A.; Perlaviciute, G.; Truskauskaitè-Kunevičienè, I. Sustainability in Youth: Environmental Considerations in Adolescence and Their Relationship to Pro-environmental Behavior. Front. Psychol. 2020, 11, 2985. [CrossRef]

5. Kollmuss, A.; Agyeman, J. Mind the gap: Why do people act environmentally and what are the barriers to pro-environmental behavior? Environ. Educ. Res. 2002, 8, 239-260. [CrossRef] 
6. Li, D.; Zhao, L.; Ma, S.; Shao, S.; Zhang, L. What influences an individual's pro-environmental behavior? A literature review. Resour. Conserv. Recycl. 2019, 146, 28-34. [CrossRef]

7. Gifford, R.; Nilsson, A. Personal and social factors that influence pro-environmental concern and behaviour: A review. Int. J. Psychol. 2014, 49, 141-157. [CrossRef]

8. Bissing-Olson, M.J.; Iyer, A.; Fielding, K.S.; Zacher, H. Relationships between daily affect and pro-environmental behavior at work: The moderating role of pro-environmental attitude. J. Organ. Behav. 2013, 34, 156-175. [CrossRef]

9. Ahmad, N.; Ullah, Z.; Arshad, M.Z.; waqas Kamran, H.; Scholz, M.; Han, H. Relationship between corporate social responsibility at the micro-level and environmental performance: The mediating role of employee pro-environmental behavior and the moderating role of gender. Sustain. Prod. Consum. 2021, 27, 1138-1148. [CrossRef]

10. Park, J.; Ha, S. Understanding pro-environmental behavior. Int. J. Retail. Distrib. Manag. 2012, 40, 388-403. [CrossRef]

11. Walder, P.; Kantelhardt, J. The environmental behaviour of farmers-capturing the diversity of perspectives with a Q methodological approach. Ecol. Econ. 2018, 143, 55-63. [CrossRef]

12. Tezel, E.; Ugural, M.; Giritli, H. Pro-environmental behavior of university students: Influence of cultural differences. Eur. J. Sustain. Dev. 2018, 7, 43. [CrossRef]

13. UNEP. Emissions Gap Report 2021. Available online: https://www.unep.org/resources/emissions-gap-report-2021?utm_term= emissions\%20gap\&utm_campaign=Search_Global_Climate_Action\&utm_source=adwords\&utm_medium=ppc\&hsa_acc=19 70971754\&hsa_cam $=15139102696 \&$ hsa_grp=128680613505\&hsa_ad=558137628912\&hsa_src=g\&hsa_tgt=kwd-146185346513 2\&hsa_kw=emissions\%20gap\&hsa_mt=p\&hsa_net=adwords\&hsa_ver=3\&gclid=CjwKCAiAm7OMBhAQEiwArvGi3Ca-5perNWFqNqNKMz0apSnSHs36zHMmMdyP900ctlKqOD0C27-exoCANMQAvD_BwE (accessed on 2 April 2021).

14. Geiger, S.M.; Geiger, M.; Wilhelm, O. Environment-specific vs. general knowledge and their role in pro-environmental behavior. Front. Psychol. 2019, 10, 718. [CrossRef] [PubMed]

15. Sonetti, G.; Brown, M.; Naboni, E. About the triggering of UN sustainable development goals and regenerative sustainability in higher education. Sustainability 2019, 11, 254. [CrossRef]

16. Zheng, S.; Cheng, Y.; Ju, Y. Understanding the intention and behavior of renting houses among the young generation: Evidence from Jinan, China. Sustainability 2019, 11, 1507. [CrossRef]

17. Jelinkova, M.; Tetrevova, L.; Vavra, J.; Munzarova, S. The Sharing Economy in the Context of Sustainable Development and Social Responsibility: The Example of the Czech Republic. Sustainability 2021, 13, 9886. [CrossRef]

18. EPI. Environmental Health. Available online: https:/ / epi.yale.edu/epi-results/2020/component/hlt (accessed on 19 July 2021).

19. Anderson, D.J.; Krettenauer, T. Connectedness to Nature and Pro-Environmental Behaviour from Early Adolescence to Adulthood: A Comparison of Urban and Rural Canada. Sustainability 2021, 13, 3655. [CrossRef]

20. Krettenauer, T. Pro-environmental behavior and adolescent moral development. J. Res. Adolesc. 2017, 27, 581-593. [CrossRef]

21. Faustini, P. The Challenges of Climate Change: Children on the Front Line; UNICEF: Italy, Florence, 2014.

22. De Leeuw, A.; Valois, P.; Ajzen, I.; Schmidt, P. Using the theory of planned behavior to identify key beliefs underlying pro-environmental behavior in high-school students: Implications for educational interventions. J. Environ. Psychol. 2015, 42, 128-138. [CrossRef]

23. Xie, H.-B.; Wu, W.-J.; Wang, Y.-F. Life-time reliability based optimization of bridge maintenance strategy considering LCA and LCC. J. Clean. Prod. 2018, 176, 36-45. [CrossRef]

24. Murtaza, S.A.; Mahmood, A.; Saleem, S.; Ahmad, N.; Sharif, M.S.; Molnár, E. Proposing Stewardship Theory as an Alternate to Explain the Relationship between CSR and Employees' Pro-Environmental Behavior. Sustainability 2021, 13, 8558. [CrossRef]

25. Gkorezis, P.; Petridou, E. Corporate social responsibility and pro-environmental behaviour: Organisational identification as a mediator. Eur. J. Int. Manag. 2017, 11, 1-18. [CrossRef]

26. Misani, N. The convergence of corporate social responsibility practices. Manag. Res. Rev. 2010, 33, 734-748. [CrossRef]

27. Russell, S.; Griffiths, A. Chapter 4 the role of emotions in driving workplace pro-environmental behaviors. In Emotions, Ethics and Decision-Making; Zerbe, W.J., Härtel, C.E.J., Ashkanasy, N.M., Eds.; Research on Emotion in Organizations; Emerald Group Publishing Limited: Bingley, UK, 2008; Volume 4, pp. 83-107.

28. Rosa, C.D.; Profice, C.C.; Collado, S. Nature experiences and adults' self-reported pro-environmental behaviors: The role of connectedness to nature and childhood nature experiences. Front. Psychol. 2018, 9, 1055. [CrossRef] [PubMed]

29. Molinario, E.; Lorenzi, C.; Bartoccioni, F.; Perucchini, P.; Bobeth, S.; Colléony, A.; Diniz, R.; Eklund, A.; Jaeger, C.; Kibbe, A. From childhood nature experiences to adult pro-environmental behaviors: An explanatory model of sustainable food consumption. Environ. Educ. Res. 2020, 26, 1137-1163. [CrossRef]

30. DeVille, N.V.; Tomasso, L.P.; Stoddard, O.P.; Wilt, G.E.; Horton, T.H.; Wolf, K.L.; Brymer, E.; Kahn, P.H.; James, P. Time Spent in Nature Is Associated with Increased Pro-Environmental Attitudes and Behaviors. Int. J. Environ. Res. Public Health 2021, 18, 7498. [CrossRef]

31. Kals, E.; Schumacher, D.; Montada, L. Emotional affinity toward nature as a motivational basis to protect nature. Environ. Behav. 1999, 31, 178-202. [CrossRef]

32. MOF. Education. Available online: https://www.finance.gov.pk/survey/chapters_19/10-Education.pdf (accessed on 21 July 2021).

33. Rhou, Y.; Singal, M.; Koh, Y. CSR and financial performance: The role of CSR awareness in the restaurant industry. Int. J. Hosp. Manag. 2016, 57, 30-39. [CrossRef] 
34. Cavaco, S.; Crifo, P. CSR and financial performance: Complementarity between environmental, social and business behaviours. Appl. Econ. 2014, 46, 3323-3338. [CrossRef]

35. Guo, M.; Ahmad, N.; Adnan, M.; Scholz, M.; Naveed, R.T. The relationship of csr and employee creativity in the hotel sector: The mediating role of job autonomy. Sustainability 2021, 13, 10032. [CrossRef]

36. Carlini, J.; Grace, D. The corporate social responsibility (CSR) internal branding model: Aligning employees' CSR awareness, knowledge, and experience to deliver positive employee performance outcomes. J. Mark. Manag. 2021, 37, 732-760. [CrossRef]

37. Seebauer, S.; Fleiß, J.; Schweighart, M. A household is not a person: Consistency of pro-environmental behavior in adult couples and the accuracy of proxy-reports. Environ. Behav. 2017, 49, 603-637. [CrossRef]

38. Rogers, R.W. A protection motivation theory of fear appeals and attitude change1. J. Psychol. 1975, 91, 93-114. [CrossRef]

39. Bockarjova, M.; Steg, L. Can Protection Motivation Theory predict pro-environmental behavior? Explaining the adoption of electric vehicles in the Netherlands. Glob. Environ. Chang. 2014, 28, 276-288. [CrossRef]

40. Keshavarz, M.; Karami, E. Farmers' pro-environmental behavior under drought: Application of protection motivation theory. J. Arid. Environ. 2016, 127, 128-136. [CrossRef]

41. Maddux, J.E.; Rogers, R.W. Protection motivation and self-efficacy: A revised theory of fear appeals and attitude change. J. Exp. Soc. Psychol. 1983, 19, 469-479. [CrossRef]

42. Prentice-Dunn, S.; Rogers, R.W. Protection motivation theory and preventive health: Beyond the health belief model. Health Educ. Res. 1986, 1, 153-161. [CrossRef]

43. Rogers, R.W.; Prentice-Dunn, S. Protection motivation theory. In Handbook of Health Behavior Research 1: Personal and Social Determinants; Gochman, D.S., Ed.; Plenum Press: New York, NY, USA, 1997; pp. 113-132.

44. Cismaru, M.; Cismaru, R.; Ono, T.; Nelson, K. "Act on climate change": An application of protection motivation theory. Soc. Mark. Q. 2011, 17, 62-84. [CrossRef]

45. Kothe, E.J.; Ling, M.; North, M.; Klas, A.; Mullan, B.A.; Novoradovskaya, L. Protection motivation theory and pro-environmental behaviour: A systematic mapping review. Aust. J. Psychol. 2019, 71, 411-432. [CrossRef]

46. Janmaimool, P. Application of protection motivation theory to investigate sustainable waste management behaviors. Sustainability 2017, 9, 1079. [CrossRef]

47. Horng, J.-S.; Hu, M.-L.M.; Teng, C.-C.C.; Lin, L. Energy saving and carbon reduction behaviors in tourism-a perception study of Asian visitors from a protection motivation theory perspective. Asia Pac. J. Tour. Res. 2014, 19, 721-735. [CrossRef]

48. Wang, Y.; Liang, J.; Yang, J.; Ma, X.; Li, X.; Wu, J.; Yang, G.; Ren, G.; Feng, Y. Analysis of the environmental behavior of farmers for non-point source pollution control and management: An integration of the theory of planned behavior and the protection motivation theory. J. Environ. Manag. 2019, 237, 15-23. [CrossRef] [PubMed]

49. Norton, T.A.; Zacher, H.; Ashkanasy, N.M. Organisational sustainability policies and employee green behaviour: The mediating role of work climate perceptions. J. Environ. Psychol. 2014, 38, 49-54. [CrossRef]

50. Wells, V.K.; Manika, D.; Gregory-Smith, D.; Taheri, B.; McCowlen, C. Heritage tourism, CSR and the role of employee environmental behaviour. Tour. Manag. 2015, 48, 399-413. [CrossRef]

51. Warrick, B.L. Examining Employee Motivation, Environmental Systems, and Corporate Social Responsibility in Proenvironmental Behavior. Ph.D. Thesis, Walden University, Minneapolis, MN, USA, 2016.

52. Fu, H.; Ye, B.H.; Law, R. You do well and I do well? The behavioral consequences of corporate social responsibility. Int. J. Hosp. Manag. 2014, 40, 62-70. [CrossRef]

53. Bozkurt, S.; Bal, Y. Investigation of the relationship between corporate social responsibility and organizational citizenship behavior: A research. Int. J. Innov. Bus. 2012, 1, 40.

54. Khan, H.A.; Zahoor, A.; Irum, S. Impacts of corporate social responsibility on employees behavior in telecom sector of Pakistan. Eur. J. Bus. Manag. 2014, 6, 34-43.

55. Ahmad, N.; Ullah, Z.; Mahmood, A.; Ariza-Montes, A.; Vega-Muñoz, A.; Han, H.; Scholz, M. Corporate social responsibility at the micro-level as a "new organizational value" for sustainability: Are females more aligned towards it? Int. J. Environ. Res. Public Health 2021, 18, 2165. [CrossRef] [PubMed]

56. Tian, Q.; Robertson, J.L. How and when does perceived CSR affect employees' engagement in voluntary pro-environmental behavior? J. Bus. Ethics 2019, 155, 399-412. [CrossRef]

57. Afsar, B.; Al-Ghazali, B.M.; Rehman, Z.U.; Umrani, W.A. Retracted: The moderating effects of employee corporate social responsibility motive attributions (substantive and symbolic) between corporate social responsibility perceptions and voluntary pro-environmental behavior. Corp. Soc. Responsib. Environ. Manag. 2020, 27, 769-785. [CrossRef]

58. Jung, Y.; Park, K.; Ahn, J. Sustainability in higher education: Perceptions of social responsibility among university students. Soc. Sci. 2019, 8, 90. [CrossRef]

59. Vázquez, J.L.; Lanero, A.; Licandro, O. Corporate social responsibility and higher education: Uruguay university students' perceptions1. Econ. Sociol. 2013, 6, 145. [CrossRef]

60. Gholamrezai, S.; Aliabadi, V.; Ataei, P. Understanding the pro-environmental behavior among green poultry farmers: Application of behavioral theories. Environ. Dev. Sustain. 2021, 23, 16100-16118. [CrossRef]

61. Gouldner, A.W. The norm of reciprocity: A preliminary statement. Am. Sociol. Rev. 1960, 25, 161-178. [CrossRef]

62. Amelang, M.; Tepe, K.; Vagt, G.; Wendt, W. A note on the development of an ecology scale. Diagnostica 1977, $23,86-88$. 
63. Rees, J.H.; Klug, S.; Bamberg, S. Guilty conscience: Motivating pro-environmental behavior by inducing negative moral emotions. Clim. Chang. 2015, 130, 439-452. [CrossRef]

64. Zelenski, J.M.; Desrochers, J.E. Can positive and self-transcendent emotions promote pro-environmental behavior? Curr. Opin. Psychol. 2021, 42, 31-35. [CrossRef] [PubMed]

65. Castro-González, S.; Vilela, B.B. The influence of emotions on the relationship between Corporate Social Responsibility and consumer loyalty. ESIC Market. Econ. Bus. J. 2016, 47, 373-396. [CrossRef]

66. Mosca, F.; Civera, C. The evolution of CSR: An integrated approach. Symphonya. Emerg. Issues Manag. 2017, 1, 16-35. [CrossRef]

67. Hur, W.-M.; Moon, T.-W.; Choi, W.-H. The role of job crafting and perceived organizational support in the link between employees' CSR perceptions and job performance: A moderated mediation model. Curr. Psychol. 2021, 40, 3151-3165. [CrossRef]

68. Kals, E.; Maes, J. Sustainable development and emotions. In Psychology of Sustainable Development; Springer: Berlin/Heidelberg, Germany, 2002; pp. 97-122.

69. Lyons, E.; Breakwell, G.M. Factors predicting environmental concern and indifference in 13-to 16-year-olds. Environ. Behav. 1994, 26, 223-238. [CrossRef]

70. Onkila, T. Pride or embarrassment? Employees' emotions and corporate social responsibility. Corp. Soc. Responsib. Environ. Manag. 2015, 22, 222-236. [CrossRef]

71. Kong, L.; Sial, M.S.; Ahmad, N.; Sehleanu, M.; Li, Z.; Zia-Ud-Din, M.; Badulescu, D. CSR as a potential motivator to shape employees' view towards nature for a sustainable workplace environment. Sustainability 2021, 13, 1499. [CrossRef]

72. D'Acunto, D.; Tuan, A.; Dalli, D.; Viglia, G.; Okumus, F. Do consumers care about CSR in their online reviews? An empirical analysis. Int. J. Hosp. Manag. 2020, 85, 102342. [CrossRef]

73. Ahmad, N.; Naveed, R.T.; Scholz, M.; Irfan, M.; Usman, M.; Ahmad, I. CSR communication through social media: A litmus test for banking consumers' loyalty. Sustainability 2021, 13, 2319. [CrossRef]

74. Afsar, B.; Al-Ghazali, B.; Umrani, W. Retracted: Corporate social responsibility, work meaningfulness, and employee engagement: The joint moderating effects of incremental moral belief and moral identity centrality. Corp. Soc. Responsib. Environ. Manag. 2020, 27, 1264-1278. [CrossRef]

75. Al-Ghazali, B.M.; Afsar, B. Retracted: Green human resource management and employees' green creativity: The roles of green behavioral intention and individual green values. Corp. Soc. Responsib. Environ. Manag. 2021, 28, 536. [CrossRef]

76. Shah, S.H.A.; Cheema, S.; Al-Ghazali, B.M.; Ali, M.; Rafiq, N. Perceived corporate social responsibility and pro-environmental behaviors: The role of organizational identification and coworker pro-environmental advocacy. Corp. Soc. Responsib. Environ. Manag. 2021, 28, 366-377. [CrossRef]

77. Suganthi, L. Examining the relationship between corporate social responsibility, performance, employees' pro-environmental behavior at work with green practices as mediator. J. Clean. Prod. 2019, 232, 739-750. [CrossRef]

78. Akhtar, S.; Khan, K.U.; Atlas, F.; Irfan, M. Stimulating student's pro-environmental behavior in higher education institutions: An ability-motivation-opportunity perspective. Environ. Dev. Sustain. 2021, 1-22. [CrossRef]

79. Dahan, G.S.; Senol, I. Corporate social responsibility in higher education institutions: Istanbul Bilgi University case. Am. Int. J. Cont. Res. 2012, 2, 95-103.

80. Rahman, A.A.; Castka, P.; Love, T. Corporate social responsibility in higher education: A study of the institutionalisation of CSR in Malaysian public universities. Corp. Soc. Responsib. Environ. Manag. 2019, 26, 916-928. [CrossRef]

81. Galvão, A.; Mendes, L.; Marques, C.; Mascarenhas, C. Factors influencing students' corporate social responsibility orientation in higher education. J. Clean. Prod. 2019, 215, 290-304. [CrossRef]

82. Binsawad, M.H. Corporate social responsibility in higher education: A PLS-SEM neural network approach. IEEE Access 2020, 8, 29125-29131. [CrossRef]

83. Chan, T.J.; Mohd Hasan, N. Corporate social responsibility practices from the employees' perspective: A case of Malaysian higher education institution. Int. J. Acad. Res. Bus. Soc. Sci. 2018, 8, 131-153. [CrossRef]

84. United Nations. World Population Prospects 2019. Available online: https://population.un.org/wpp/Graphs/Probabilistic/ POP/TOT/586 (accessed on 1 August 2021).

85. Robert, H. Education in Pakistan. Available online: https://wenr.wes.org/2020/02/education-in-pakistan (accessed on 1 August 2021).

86. Worldometer. Pakistan Population. Available online: https://www.worldometers.info/world-population/pakistan-population/ (accessed on 2 August 2021).

87. Bakht, R. Emerging Trends and Challenges to Higher Education in Pakistan. Available online: https://www.thenews.com.pk/ print/833031-emerging-trends-and-challenges-to-higher-education-in-pakistan (accessed on 2 August 2021).

88. Shakil, S. Higher Education Systems and Institutions, Pakistan. In Encyclopedia of International Higher Education Systems and Institutions; Springer: Dordrecht, The Netherlands, 2018; pp. 1-8.

89. IQAir. Air Quality in Pakistan. Available online: https:/ / www.iqair.com/us / pakistan (accessed on 9 May 2021).

90. Gjersing, L.; Caplehorn, J.R.; Clausen, T. Cross-cultural adaptation of research instruments: Language, setting, time and statistical considerations. BMC Med. Res. Methodol. 2010, 10, 13. [CrossRef] [PubMed]

91. Fernández-Gómez, E.; Martín-Salvador, A.; Luque-Vara, T.; Sánchez-Ojeda, M.A.; Navarro-Prado, S.; Enrique-Mirón, C. Content validation through expert judgement of an instrument on the nutritional knowledge, beliefs, and habits of pregnant women. Nutrients 2020, 12, 1136. [CrossRef]

92. Declaration, H. Human experimentation: Code of ethics of World Medical Association Br. Br. Med. J. $1964,2,18$. 
93. Turker, D. Measuring corporate social responsibility: A scale development study. J. Bus. Ethics 2009, 85, 411-427. [CrossRef]

94. Droms Hatch, C.; Stephen, S.-A. Gender effects on perceptions of individual and corporate social responsibility. J. Appl. Bus. Econ. 2015, 17, 63.

95. Nejati, M.; Nejati, M. Assessment of sustainable university factors from the perspective of university students. J. Clean. Prod. 2013, 48, 101-107. [CrossRef]

96. Robertson, J.L.; Barling, J. Greening organizations through leaders' influence on employees' pro-environmental behaviors. J. Organ. Behav. 2013, 34, 176-194. [CrossRef]

97. Müller, M.M.; Kals, E.; Pansa, R. Adolescents' emotional affinity toward nature: A cross-societal study. J. Dev. Process. 2009, 4, 59-69.

98. Ito, K.; Leung, A.K.-y.; Huang, T. Why do cosmopolitan individuals tend to be more pro-environmentally committed? The mediating pathways via knowledge acquisition and emotional affinity toward nature. J. Environ. Psychol. 2020, 68, 101395. [CrossRef]

99. Podsakoff, P.M.; Organ, D.W. Self-reports in organizational research: Problems and prospects. J. Manag. 1986, 12, 531-544. [CrossRef]

100. Chang, S.-J.; Van Witteloostuijn, A.; Eden, L. From the editors: Common method variance in international business research. J. Int. Bus. Stud. 2010, 41, 178-184. [CrossRef]

101. Harman, H.H. Modern Factor Analysis; University of Chicago press: Chicago, IL, USA, 1976.

102. Fornell, C.; Larcker, D.F. Evaluating structural equation models with unobservable variables and measurement error. J. Mark. Res. 1981, 18, 39-50. [CrossRef]

103. Gefen, D.; Straub, D.; Boudreau, M.-C. Structural equation modeling and regression: Guidelines for research practice. Commun. Assoc. Inf. Syst. 2000, 4, 7. [CrossRef]

104. Afsar, B.; Umrani, W.A. Corporate social responsibility and pro-environmental behavior at workplace: The role of moral reflectiveness, coworker advocacy, and environmental commitment. Corp. Soc. Responsib. Environ. Manag. 2020, 27, 109-125. [CrossRef]

105. Raza, A.; Farrukh, M.; Iqbal, M.K.; Farhan, M.; Wu, Y. Corporate social responsibility and employees' voluntary pro-environmental behavior: The role of organizational pride and employee engagement. Corp. Soc. Responsib. Environ. Manag. 2021, 28, 1104-1116. [CrossRef]

106. Bhattacharyya, A.; Biswas, K.; Moyeen, A. Determinants of Pro-environmental Behaviours-A Cross Country Study of Would-be Managers. Australas. Account. Bus. Financ. J. 2020, 14, 51-71. [CrossRef]

107. Kerret, D.; Orkibi, H.; Bukchin, S.; Ronen, T. Two for one: Achieving both pro-environmental behavior and subjective well-being by implementing environmental-hope-enhancing programs in schools. J. Environ. Educ. 2020, 51, 434-448. [CrossRef]

108. Schultz, P. Empathizing with nature: The effects of perspective taking on concern for environmental issues. J. Soc. Issues+ 2000, 56, 391-406. [CrossRef]

109. Petrenko, O.V.; Aime, F.; Ridge, J.; Hill, A. Corporate social responsibility or CEO narcissism? CSR motivations and organizational performance. Strateg. Manag. J. 2016, 37, 262-279. [CrossRef]

110. Huang, C.-F.; Lien, H.-C. An empirical analysis of the influences of corporate social responsibility on organizational performance of Taiwan's construction industry: Using corporate image as a mediator. Constr. Manag. Econ. 2012, 30, 263-275. [CrossRef] 